\title{
Information, Announcement, and Listing Effects of ADR Programs and German-U.S. Stock Market Integration*
}

\author{
Michael Hertzel \\ Arizona State University, U.S.A. \\ Paul Lowengrub \\ Nathan Associates, U.S.A. \\ Michael Melvin \\ Arizona State University, U.S.A.
}

This article analyzes the impact on stock prices in the home market of important events associated with a U.S. listing. Events include the "filing effect" of financial statements made public by the SEC in preparation for an ADR program; the "announcement effect" of the forthcoming ADR program; and the "listing effect" of the first day of U.S. trading. The sample includes German firms that listed in the U.S. between 1991 and 1997. While German accounting standards allow firms to show profits when U.S. GAAP would show losses, we find that the reconciliation to U.S. GAAP reported in the "filing effect" is associated with positive abnormal returns. Perhaps this reflects selfselection where firms with nothing to hide list in the U.S. The announcement effects are mixed across firms. The listing effect is associated with positive abnormal returns. We also find some evidence of volume migrating from the home market to the U.S. after U.S. trading begins (JEL F3).

Keywords: ADRs, international cross-listing, international equity markets, German stocks.

\footnotetext{
*Useful comments on an earlier draft were received from an anonymous referee, the editor, and participants at the Kiel Workshop on The Integration of Financial Markets in Europe and seminars at the University of Frankfurt, University of Karlsruhe, and the Center for European Integration Studies in Bonn.
}

(Multinational Finance Journal, 2000, vol. 4, no. 3\&4, pp. 181-200)

CMultinational Finance Society, a nonprofit corporation. All rights reserved.

DOI: $10.17578 / 4-3 / 4-3$ 


\section{Introduction}

This article provides an analysis of some important home-market implications of foreign firms that list their shares in the United States capital market. In particular, the impact on stock prices in the home market of important "events" associated with listing in the United States is analyzed. The focus is on German firms due to the availability of transactions data from the German home market that allows a long enough time series to conduct a pre- and post-listing analysis and the differences in accounting standards existing between the two countries. While the sample of firms is small, the results justify the analysis at the level of the individual firm rather than at an aggregate level across firms, which is the standard approach in the literature. We demonstrate that results may differ across firms in important ways that are obscured by an aggregate analysis so that researchers may find a detailed analysis at the firm level more fruitful than studying aggregates across firms.

German firms are traded in the United States as American Depositary Receipts (ADRs). ${ }^{1}$ The process of creating an ADR and listing in the United States proceeds in distinct steps. This article examines the effect of the three major public events on returns in the home market. First, it examines the "information effect" of financial statement filings with the SEC in preparation for the ADR program. Second, the "public announcement effect" of the forthcoming ADR program is estimated. Third, the "listing effect" of the start of trading in the United States is estimated.

German ADRs were selected for the analysis performed in this paper since under German accounting standards it is possible for firms to present financial statements displaying profits when U.S. standards would result in displaying losses. The "information effect" analysis asks whether there is any information revealed when German firms submit form $20-F$ to the SEC. By analyzing the domestic price impact of the SEC filing, we can determine if negative information is revealed when the German firms reconcile their financial statements with US GAAP. Beyond this SEC filing effect, the paper also examines the impact of the

1. An appendix providing a description of ADRs is available upon request from the authors. 
first announcement of the ADR program (announcement effect) and the start of trading for the ADR (listing date).

In terms of the microstructure of the international equity market, the filing and announcement effects may be thought of as pure public information events while the listing effect captures the initial impact of a change in market design. With regard to the impact of new information revealed by a firm's SEC filing, there is no expected sign for the price effect. Positive signs would indicate that the U.S. financial statements reveal better news than expected. For instance, even if the news indicates that the firm is in worse financial condition than conveyed by German financial statements, it is possible that the market expected even worse news so that a positive price impact is observed. A negative SEC filing effect would occur if the news was, indeed, worse than anticipated. Similarly, the announcement effect on price could be positive or negative. If investors believe that negative information will be revealed, then price may fall when the intent to list in the United States is made public. However, since international listing is a voluntary act, we might expect that only firms with nothing to hide would participate. In this case, the announcement of plans for a U.S. listing may be interpreted as a signal of firm quality that results in a positive price impact.

The public news events associated with a German firm cross-listing in the United States may also yield evidence of whether the asymmetric information existing between firm insiders and the rest of the market has an impact on market dynamics. If one can observe price moving prior to the public news event, then this may be evidence of informed trading. Certainly there are individuals who have participated in the preparation of financial statements or who are aware of the firm's intent to list prior to the news becoming public. It is even possible that such informed trading has already provided a signal to the public prior to the information event so that no price impact is observed.

The listing effect on price in the home country when U.S. trading begins provides an indication of how a change in the market design affects market dynamics. The opportunity to trade past European business hours in a highly liquid market could have positive or negative effects on the German price. If the cost of capital to German firms falls with the U.S. listing, we might expect this to reduce the price in Germany as the risk premium built into the cost of capital falls. 
However, this may be countered by a positive price impact associated with higher-than-anticipated interest in the United States in trading the firm. A related microstructure effect involves the likely positive impact on German trading of lower transaction costs due to competition for order flow with the United States market. While home-market trading generally is much larger than ADR trading for most firms, the advent of a new trading venue in the world's largest capital market should be expected to lower trading costs in the home market.

The remainder of the paper proceeds as follows: Section II presents the data employed in the study. Section III discusses the information, announcement, and listing effects and provides evidence regarding the effects of these events on the stock prices in the home market. Finally, Section IV offers a summary and conclusions.

\section{Data}

The focus of this paper is on ADRs for German firms. ADRs are U.S.dollar-denominated negotiable instruments issued by a depositary bank that represent ownership in non-U.S. securities. ADRs enable U.S. investors to acquire and trade non-U.S. securities denominated in U.S. dollars without concern for the differing settlement timetables and other problems typically associated with overseas markets. In order to be included in our sample of ADRs, a firm must satisfy the following criteria:

Started a Level I, II, III and/or 144a Sponsored ADR program between 1991 and 1997.

Listed on the Integrated Stock Exchange Trading and Information System (IBIS).

Have 3 months of intradaily data before and after the start of the Level I, II, III and/or 144a sponsored ADR program.

The sample was formed by first identifying all German ADR programs in the United States. The Bank of New York provides the master list of all ADRs on their ADR home page via the Internet. ${ }^{2}$ However, the Bank of New York's list does not take into account firms that have delisted or ceased their ADR program during our time period.

2. See www.adrbny.com. 
Therefore, additional sources were used to identify current German ADRs, including Deutsche Bank, ADR-Net and Bankers Trust. McGraw Hill's Handbook of ADR's also provides a current list. It was determined that there were 52 German ADRs currently listed on the U.S. markets.

The next step was to identify those firms that started a Level I, II, III and/or 144a Sponsored ADR program between 1991 and 1997. It was determined that 23 firms fit this requirement. All 23 firms were listed on the Integrated Stock Exchange Trading and Information System(IBIS). Of the 23 firms, only 11 had sufficient historical data to be used for this empirical analysis. ${ }^{3}$ For instance, Adidas, which is a 144a, went public in Germany around the same time they established an ADR program in the United States. Therefore, no historical data exist. The same problem occurs with Deutsche Telekom, Puma, Merck, and Mannesman. The breakdown of the final list of ADRs available to be studied is the following:

Level I Sponsored ADR: Bayer, Bayerische Vereinsbank, Deutsche Bank, Dresdner Bank, Kloeckner Werke, RWE AG, and Thyssen. Level II Sponsored ADR: Hoechst and Veba

Level III Sponsored ADR: Daimler Benz and SGL Carbon.

The 144a firm is Dresdner Bank. ${ }^{4}$

The data for the empirical analysis were supplied by the Karlsruhe Kapitalmarketdatenbank (KKMDB). The data are intradaily prices from Germany as quoted on the IBIS trading system. IBIS is an integral part of the Frankfurt Stock Exchange (FSE). It was introduced on April 5, 1991. ${ }^{5}$ Trading takes place from 8:30 a.m. until 5:00 p.m. The IBIS data set comprises time-stamped prices and volume for all trades since July 1,1991 .

3. The empirical analysis requires at least 3 months of data before and after starting a sponsored ADR program.

4. Note: a firm can establish a 144a program along with a Level I program. The 144a is for capital raising with institutional buyers. In terms of dating events associated with Dresdner Bank, the announcement date is with regard to the earlier 144a program and the listing date is with regard to the later Level 1 program.

5. On November 28, 1997, the IBIS system was replaced with the Xetra system. Xetra is a faster, more efficient trading system, but changes nothing as far as the implications of our paper as it essentially retains the same functionality as IBIS. 


\section{Filing, Announcement, and Listing Effects}

The analysis in this section is partly motivated by the contrasting viewpoints held by the U.S. Securities and Exchange Commission (SEC) and the New York Stock Exchange (NYSE) regarding disclosure requirements for foreign firms listing in the United States. In a nutshell, the SEC position is that investors and issuers benefit from a policy requiring all corporations utilizing the U.S. capital markets to abide by the same rules. Furthermore, if more lax disclosure requirements were given to foreign firms, domestic firms might be at a competitive disadvantage as they will incur higher costs to comply with SEC regulations. The NYSE has argued that the SEC's stringent disclosure requirements impede the globalization of capital markets and puts U.S. security exchanges at a competitive disadvantage in their effort to attract more foreign listings. In addition, the NYSE has claimed that only the securities from first-class companies which have little incentive to deceive investors would be listed. Presumably, this would mean that only firms who have nothing to hide would be interested in listing. In this case, financial statements based on foreign GAAP would not be significantly different from those based on U.S. GAAP.

It is the latter point that our analysis partially addresses. We first examine the filing effect of German firms in terms of analyzing the effect on home-market returns of public disclosure of financial statements filed with the SEC that conform to U.S. GAAP. We will be able to make inferences regarding whether release of financial statements conforming to U.S. GAAP provides any useful news to investors.

Beyond the filing effect, we examine a related event, the announcement effect. In this case, we analyze the effect on homemarket returns of the first announcement of intention to create an ADR program. Aside from the actual release of financial statements conforming to U.S. GAAP, the market should discount the information that is expected to be revealed by the filing with the SEC. If investors believe that German firms will reveal negative information by conforming to U.S. GAAP, then we would expect that the announcement of an ADR program is associated with negative returns. On the other hand, one might expect a selection bias so that firms who 
could reveal bad news would choose not to list. If ADR programs were not expected to confer benefits upon the listing firm, then no firm supported listings would occur. For instance, one might expect the effect of a broadened market for a firm's stock to result in positive returns.

In addition to the two public information events just discussed, we also examine the impact of a change in market design, the listing effect - the effect of the first day of ADR trading on home-market returns. If, in fact, a broadened market for a firm's stock results in more liquid trading and positive returns, we might ask why market participants did not discount the effect of the start of trading. One potential answer is that the market response to the ADR may be greater than anticipated. One cannot, with certainty, forecast the trading volume in a new listing and the listing effect in the home market may be a signal of the volume surprise associated with the early ADR trading. This effect is not unlike the "liquidity effect" associated with the inclusion of a firm in the S\&P 500. If we know the firm is to be included, yet there is still a positive abnormal return associated with the date the inclusion occurs, this may simply signal that demand was stronger than expected rather than any inefficiency.

\section{A. The Filing Effect}

According to the NYSE view, foreign firms are discouraged from listing on the U.S. stock markets by the stringent financial reporting requirements of the SEC. There is some earlier research that supports this argument. Choi and Levich (1990) examine responses from seniorlevel managers representing corporate institutional investment, underwriting, and regulatory bodies, as to whether accounting diversity affects their capital market decisions. Their paper employs personal interviews and open-ended surveys to examine responses from representatives of 52 institutions (15 corporations) headquartered in Frankfurt, London, New York, Tokyo and Zurich. Choi and Levich report that of the 11 non-US firms surveyed, 6 avoided raising funds or listing their shares in the US due to concerns about accounting disclosures. Saudagaran and Biddle (1994) examine the relationship between financial disclosure levels and firms' decisions regarding listing on nine stock exchanges from eight countries (both the NYSE and AMEX are included). They find evidence that an inverse relationship exists between the disclosure level and the probability of a firm listing on 
an exchange. Saudagaran and Biddle (1994) find support for the following two hypotheses. 1) Firms will be more likely to list on foreign stock exchanges with lower financial disclosure levels than their domicile and 2) firms will be more likely to list on foreign stock exchanges in countries that represent larger markets for the firm's products. These papers support the NYSE claim that foreign firms are discouraged from listing in the United States due to the stringent requirements of the SEC.

An attractive feature of the filing effect analysis is the clear identification of the relevant date. The date when firms' reconciled financial statements become public information is provided by the SEC and is identified as the day when the form $20-\mathrm{F}$ is made public to investors.

The firms that are included in the filing analysis are those with level 2 and 3 ADRs that have historical data on the IBIS system. The sample includes the following firms: Daimler Benz, Hoechst, and Veba. ${ }^{6}$ The reason for using only level 2 and 3 ADRs is because these firms must fully comply with U.S. GAAP accounting standards and file form 20-F.

\section{B. The Announcement Effect}

International asset pricing models suggest that when investors realize barriers to investments are to be removed, expected future returns should decrease as prices are bid up on the expectation of the removal of the barriers. Therefore, one approach to studying the impact of the establishment of an ADR program is to examine the market reactions around the announcement of an ADR program.

A theoretical analysis of the announcement issue is provided by Cantale (1996) and Fuerst (1998). Both papers view a decision to list in a foreign market as a signal to investors. Particularly, listing in a market with a stricter disclosure and regulatory environment sends a signal regarding the high quality of the firm and its prospects for the future. In this view, abnormal returns associated with the announcement of an ADR program are more a result of changes in information flows than an issue of market segmentation barriers.

Although announcement dates are theoretically more appropriate than listing dates in order to test the impact of the ADR program on firm

6. SGL Carbon lacks historical data on the IBIS data set prior to the filing date so they were omitted from the sample. 
value, data collection presents some challenges. The most commonly used data source for announcements is Lexis/Nexis, which includes hundreds of information sources. However, even if Lexis/Nexis captures what is known in the market, the definition of the announcement date is controversial. For example, in some cases markets have expected for years that a firm will eventually list in the US. Sometimes, a company spokesperson indicates that a firm is contemplating crosslisting but the firm has not received board approval; and in other cases a firm has received board approval but has not received approval from the SEC. In two of our cases, the SEC filing date was prior to the announcement date. It can also take almost two years for a firm to list. For example, Daimler Benz announced its ADR program in 1991 and did not list until October of 1993. Our research indicates that Lexis/Nexis news searches may, in some cases, provide misleading announcement dates. This is a result that others have also found. For instance, Foerster and Karolyi (1999) found that Grand Metropolitan announced on November 1, 1989 that it was applying to list on the NYSE. Then on June 2, 1990, it announced a postponement in the listing. Next, it announced that it was again seeking a NYSE listing, which finally occurred on March 13, 1991. In this case, can we discuss and estimate effects of only one announcement date?

We began our search for announcement dates in the same manner as other researchers: searching Lexis/Nexis for related news stories over the 3-year period prior to listing. Rather than just search for news about ADRs, we read every article about a firm during the 3 years prior to listing to ensure that no relevant news was missed. In addition, we found that one cannot simply rely on one or a few Lexis/Nexis databases. Only a search over all databases can safely provide the earliest announcement date. Even then, we found that by checking the Lexis/Nexis results against a search using the Dow Jones news retrieval service would sometimes reveal an even earlier piece of news. Finally, we spoke to partners at the major depositaries in New York to confirm our dates.

Firms with clearly identifiable announcement dates are: Bayerische Vereinsbank, Bayer A.G., Daimler Benz, Deutsche Bank, Dresdner Bank, Hoechst, RWE A.G., SGL Carbon and Veba. We were not able to find announcement dates for Thyssen and Kloeckner Werke. 


\section{The Listing Effect}

Once trading in the United States begins, we may expect prices to reflect the new market design incorporating global financial integration. This market integration hypothesis is based on the notion that there should be positive excess returns prior to the listing date and negative abnormal returns in the post-event period if the markets are integrated. This is because an international listing can eliminate a risk premium that is built into the cost of capital of a firm in a segmented market. After crosslisting, the cost of capital should decline and the risk premium should be dissipated.

The prior evidence shows that there are positive abnormal returns at and around the listing of the ADR programs and negative returns over the post-listing period consistent with a new market design that reduces the risk premium that was attached to firms trading in segmented markets. $^{7}$

\section{Empirical Results}

An event study methodology is used to analyze the impact on firm value around the SEC filing, announcement, and listing dates. A three-day event period $\{-1,0,1\}$ from one day prior to one day after the filing, announcement, and listing dates is employed. To measure abnormal

returns, we estimate a market model formulation that includes a dummy variable to capture the shift in return on the event date. The model specification is:

$$
\begin{gathered}
R_{i, t}=\alpha_{i}+\beta_{i} R_{m, t}+\gamma_{i} D_{i, t}+\varepsilon_{i, t}, \\
E\left(\varepsilon_{i, t}\right)=0, \operatorname{var}\left(\varepsilon_{i, t}\right)=\sigma_{i, t}^{2}
\end{gathered}
$$

where $R_{i, t}$ and $R_{m, t}$ are the period- $t$ returns on security $i$ and the market portfolio, respectively, and $\varepsilon_{i, t}$ is a zero mean disturbance term. $D_{i, t}$ is a dummy variable that takes a value of 1 for the event period. Finally, $\alpha$, $\beta$, and $\gamma$ are the parameters to be estimated. The DAX 100 Index is our

7. Theoretical models of these effects are provided in Stapleton and Subrahmanyam (1977), Errunza and Losq (1985), and Alexander et al. (1988). Empirical support is given in Alexander et al., Foerster and Karolyi (1993, 1999), and Miller (1999). 
proxy for the market portfolio. ${ }^{8}$ The estimated coefficient on the dummy variable is intended to capture the abnormal return. We estimate a separate model for each event day.

The sample for the SEC filing date analysis includes 150 trading days prior to the event period and 60 trading days after the event. The sample period for the announcement date analysis includes 140 trading days prior to the event period and 80 trading days after the event period. The sample period for the listing date analysis includes 180 trading days prior to the event period and 60 trading days after the event period for all but 4 firms. The last firms to list (Kloeckner Werke, Veba, Thyssen, and Bayerische Vereinsbank) only have 30 days after listing in the sample. Different sample sizes are a function of different event dates. Since the residuals of the equation above were found to have autoregressive heteroskedasticity, we estimated the model in a GARCH framework.

Estimates of the event-specific dummy variable coefficients are reported in table 1. Three separate estimates are reported for each event: $\{-1\}$ represents the day before the event; $\{0\}$ represents the day of the event; and $\{+1\}$ represents the day after the event.

\section{Filing Effect}

There are only 3 firms with data relevant to the filing of Form 20-F. We see that on the day of filing, all 3 firms have significantly positive abnormal returns. This may be interpreted as the firms revealing information that was better than expected. The reconciliation of German financial statements with U.S. GAAP provided positive news to the market.

Aside from the event day itself, we also examine the day before and after the event. The $\{-1\}$ day estimate may reflect the asymmetric information that exists in the market or leakage due to insider trading or it may simply reflect the market's anticipation of the news to be received the next day. On the day before filing, Hoechst has a significantly negative abnormal return, Veba has a significantly positive abnormal return, and Daimler Benz has an insignificant coefficient. Only in the case of Veba is there evidence consistent with the sort of leakage associated with privately-informed trading.

8. We also used the German weighted market capitalization index but the results were almost identical to the DAX 100 index results reported. 


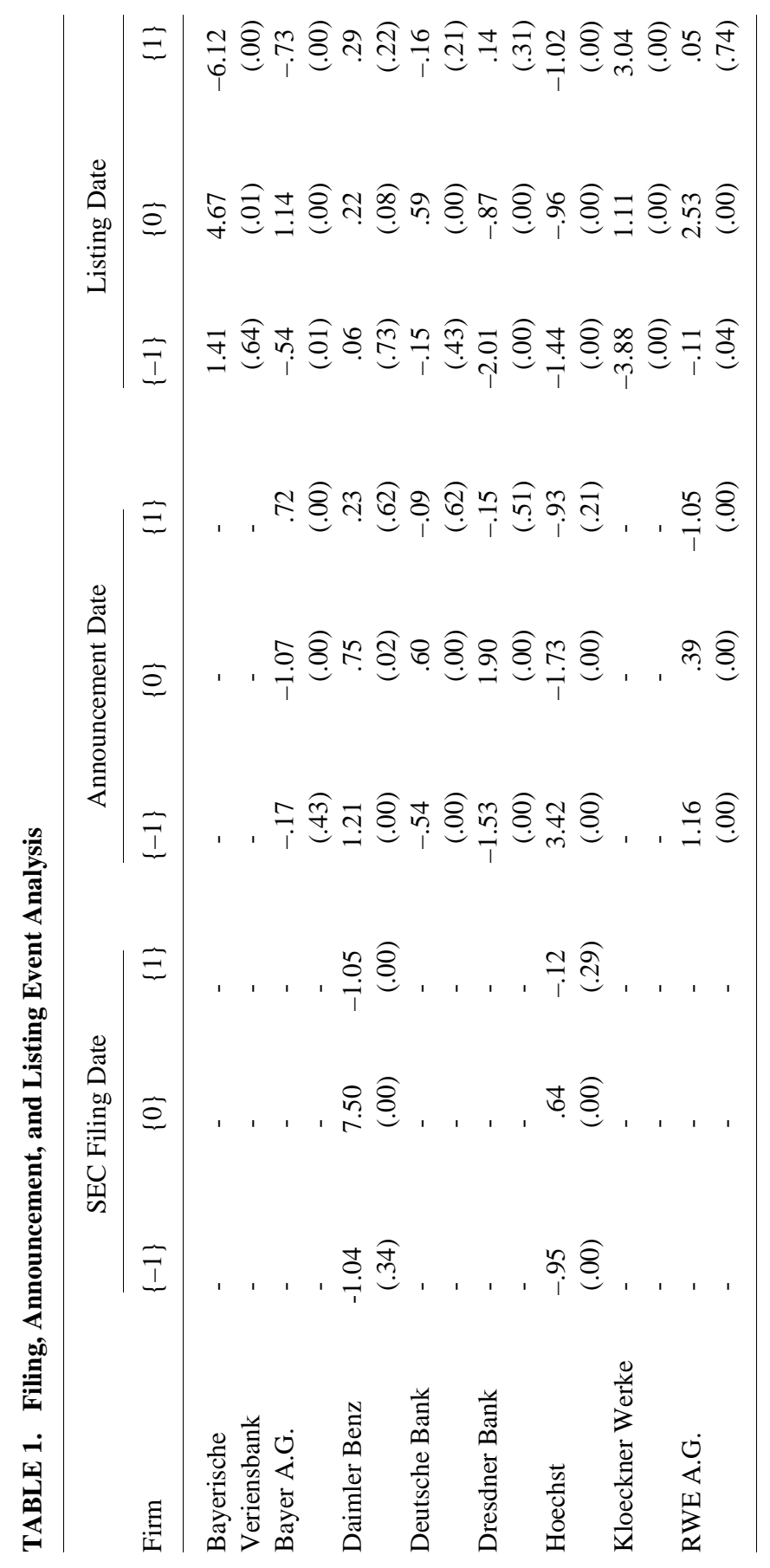




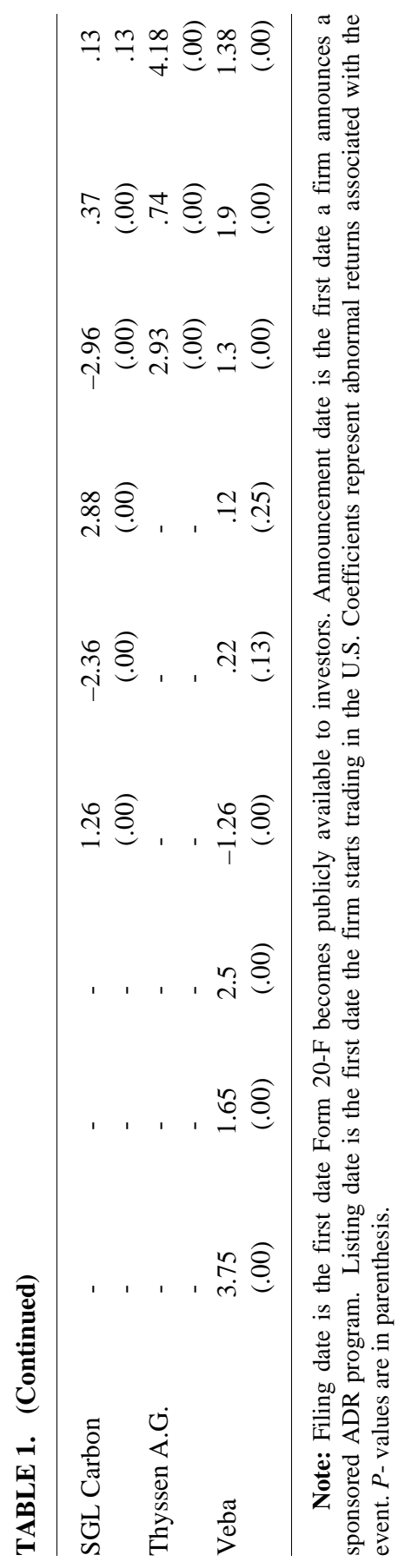


The day after the event $\{1\}$, may reflect the continued market digestion of the news, bandwagon effects, or a correction to a market overreaction the prior day. In table 1 , we see a significantly negative abnormal return for Daimler Benz following the strong positive abnormal return on the event day. This is consistent with correction of an overreaction by the market on the event day. Veba has a positive abnormal return following the positive returns of the two prior days. This is consistent with a continuing market digestion of the filing news. There is no significant response for Hoechst. This suggests that the event-day price change was viewed by the market as a complete adjustment to the news.

While the data constrain us to a small sample, taken as a whole, it appears that the filing event does yield information that is valued by the market. Given the differences between German and U.S. accounting standards, these results may suggest that those German firms that choose to list in the United States have little or nothing to hide. A selfselection process may ensure that German firms starting ADR programs provide support for the NYSE position that conforming to U.S. GAAP may be an unnecessary hurdle. An alternative hypothesis is that the reconciliation with U.S. GAAP did provide unfavorable news to investors, but the news was not as bad as expected. In this case, it could be argued that the SEC position is supported. Without information on expectations, one cannot settle this debate with the results presented here.

\section{Announcement Event}

As discussed above, previous researchers have found positive abnormal returns associated with announcements of forthcoming ADR programs. Earlier studies have tended to look across a broad spectrum of issuer countries. We know that the differences between German and U.S. accounting standards makes the analysis of German ADRs particularly useful to study the information effect of announcements. There should be a negative effect of announcements if investors believe that financial statement reconciliation inevitably leads to bad news. On the other hand, if the announcement is interpreted as a signal regarding the good future prospects of the firm or the expected broadening of the market for a firm's shares, then the message may be good news.

The middle section of table 1 reports the estimates of the 
announcement effect. On the event day $\{0\}$, all except Veba have statistically significant effects. Interestingly, the abnormal returns are negative for three firms and positive for four. These mixed results suggest that the market anticipates the information associated with financial statement reconciliation to be negative and important for Bayer, Hoechst, and SGL Carbon. The positive signalling effect seems to dominate for Daimler Benz, Deutsche Bank, Dresdner Bank, and RWE A.G.

For the day prior to the event $\{-1\}$, anticipation of the event day effect is seen for Daimler Benz and RWE A.G. This is consistent with privately-informed trading moving the market in the direction of the response on the event day. Opposite effects are seen for Deutsche Bank, Dresdner Bank, Hoechst, and SGL Carbon. These results are consistent with privately informed trading pushing price too far in one direction so that on the event day, the market corrects the price overreaction. In addition, there is a significant negative effect for Veba. On the post-event day $\{1\}$, only 3 firms have a significant estimate and all 3 cases are opposite the effect on the event day. This is also consistent with the market correcting for a price overreaction on the event day.

While the announcement day results are interesting, caution is urged in viewing any announcement day effects. There is no guarantee that the date identified is truly the first day the information is revealed to the market. In the case of the filing and listing events, one can objectively identify the day of filing and the first day of trading. The announcement date is identified by a literature search that may or may not reveal the proper date. The current study is likely to have gone to greater lengths to identify announcement dates than anyone prior, but the unavoidable arbitrariness of the search process should lead to humility in presenting any results on announcement effects.

\section{Listing Effect}

If the listing date is known with certainty, then one might argue that the effect should already be discounted in the home market so that there is no significant effect on the event date. Alternatively, perhaps the listing date is a surprise to all but insiders or there is a surprising liquidity effect with the start of trading, then we might expect to observe a listing effect.

The right side of table 1 reports results for the listing effect. On the 
event day $\{0\}$, there is a statistically significant effect for all firms. All but two, have positive abnormal returns. The negative abnormal returns of Dresdner Bank and Hoechst may reflect less interest in trading the new ADR than expected. However, note the negative abnormal returns on the day prior to the event for these two firms. The event day continuation of the price movement on the prior day is also consistent with a fall in the risk premium associated with German trading in these firms once U.S. trading begins. This price movement may have been started by privately informed traders on the day prior to the event. For the other firms, the broadening of the shareholder base is associated with positive abnormal returns. As was argued earlier, a change in market design that increases global competition for order flow may be expected to lower trading costs, which could, in turn stimulate demand for the affected firms.

On the day prior to the event $\{-1\}$, there is a correct anticipation of the event day effect for four firms. Four other firms have an anticipation effect in the opposite direction of the event day effect and all four are negative on $\{-1\}$ while the event day effect is positive. If the prior day trading reflects privately-informed trades, then the evidence suggests that such trades for four firms results in a price overreaction that is then corrected on the event day.

On the day after listing, two firms have a negative return following a positive event day return, three firms have a positive return following a positive event day return, and one firm has a negative return following a negative event day return. In the latter four cases, the day-after price change reinforced the event day return. This suggests that the market is still learning about the implications of the change in trading regime and this price-continuation effect may not be surprising since the full day of U.S. trading will not be revealed until after the event day closing in Germany so that day $\{1\}$ trading in Germany will partially reflect the listing event information revealed in the United States. Only two firms indicate that the day after listing the market corrects a price overreaction on the event day.

\section{E. Volume Effects}

The issue of German firms starting an ADR program raises an important question: What happens to trading volume in Germany when the firm 
starts an ADR program? In particular is global trading a zero-sum game? For example, if $29 \%$ of trading for Daimler Benz is in the United States, does this mean that there is $29 \%$ less trading in Germany than there was before the ADR?

The effects of such a change in market design has been studied at the aggregate level by Smith and Sofianos (1997). They examine 128 non-US stocks that listed on the NYSE between January 1, 1985 and July 31, 1996. The NYSE and home market combined trading volume increased by $42 \%$ compared to the volume prior to NYSE listing. Looking at only the home market, trading volume increased $24 \%$. These results suggest that on average foreign listings on the NYSE are not a zero-sum game but a win-win situation for both the home and US markets. One may wonder how results may differ by focusing the analysis at the level of the individual firm rather than averaging across a large number of firms.

For the sample of German firms in this study, we compute the average daily trading volume for 30 days pre and post-listing and report the results in table 2 . Pooling all firms results in a statistically significant increase in daily volume. However, the results are more revealing at the individual firm level. In seven cases, average daily German trading volume increases after the U.S. listing. This is consistent with the findings of Smith and Sofianos regarding NYSE firms and is what we would expect if the new market design enlarges opportunities to trade and lowers trading costs. However, in four cases, there is a statistically significant decrease in average daily volume and one of these firms, Daimler Benz, is traded on the NYSE. This indicates that some German trading volume has migrated to the United States. Thus, the results for the German market are mixed. The majority of cases indicate that the German market benefits from a U.S. listing, but there are counterexamples that suggest otherwise. Our results indicate that the issue is better examined at the level of the individual firm than in the aggregate. Had we conducted the before and after listing comparison for all firms, we would have found a statistically significant increase in mean daily volume. Thus, the aggregate results mask the variation that occurs across individual firms. 
TABLE 2. Average Firm Specific Volume before and after Listing Dates

\begin{tabular}{lrc}
\hline Firm & $\begin{array}{c}\text { Average Daily Volume } \\
\text { before Listing Date }\end{array}$ & $\begin{array}{c}\text { Average Daily Volume } \\
\text { after Listing date }\end{array}$ \\
\hline Bayerische Vereinsbank & 739,333 & 750,933 \\
Bayer & 224,900 & 218,833 \\
Daimler Benz & 602,033 & 499,533 \\
Deutsche Bank & $1,417,033$ & $1,689,533$ \\
Dresdner Bank & 49,167 & 100,933 \\
Hoechst & $2,270,933$ & $2,280,267$ \\
Kloeckner Werke & 26,940 & 16,580 \\
RWE A.G. & 144,167 & 124,300 \\
SGL Carbon & 23,900 & 74,480 \\
Thyssen & 209,733 & 222,167 \\
Veba & $1,581,133$ & $1,803,333$ \\
All Firms & $7,289,273$ & $7,780,893$ \\
\hline
\end{tabular}

Note: All before and after means are significantly different at the $95 \%$ level of confidence

\section{Conclusions}

We have examined important areas of interest related to the start of an ADR program: the public information impact of the effects of filing reconciled financial statements with the SEC (the filing effect) and announcing the planned ADR program (the announcement effect), and the impact of a change in market design associated with the start of trading the ADR (the listing effect). Given the differences between German and U.S. accounting standards, the information content of the filing and announcement effect is particularly interesting for our sample of German firms. We find that the filing effect is associated with positive abnormal returns so that German firms are providing good news to the market with the SEC filing. This may be interpreted as firms following a self-selection process so that those firms volunteering to report financial statements that conform to U.S. GAAP have nothing negative to conceal. The announcement day effects are mixed between positive and negative abnormal returns. In some cases, the market 
appears to view the announcement of a program as bad news while in other cases, good news. Given the arbitrariness of the search process in identifying announcement dates, caution is urged in interpreting any announcement effect studies (including ours). Finally, the listing effect is one of positive abnormal returns for all but two firms. The German home market trading may serve as a signal of the unexpected component of first day ADR trading. A positive abnormal return in Germany may reflect stronger than expected demand for the ADR, while a negative abnormal return may reflect weaker than expected demand for the ADR. A positive return is expected if the new market design increases competition for order flow and stimulates demand for the stock due to lower trading costs. A negative return is expected if the opportunities to trade on a large and liquid capital market decrease the risk premium embedded in a firm's price due to market segmentation.

Taken as a whole, each of the events is seen to be value relevant to the market. One conclusion we reach regarding ADR-related events is the importance of viewing firm-specific results. Aggregate results may hide important differences that exist across firms. An example is the effect of the listing on German home market volume. If we pool all firms, we find evidence of a significantly positive increase in average daily trading in Germany following the ADR listing. This is the result we expect if trading costs fall and greater liquidity is provided by the new market design. However, by examining trading volume at the level of the individual firm, we find that some firms experienced a significant drop in home market volume following the ADR trading in the United States. This is consistent with a migration of trading to the United States. Since two of the firms with lower German trading volume are the biggest multinational firms in our sample (Bayer and Daimler Benz), this negative effect may reflect greater global interest in the firms and a consequent greater interest in trading on a market outside of Germany. Regardless of the exact reasons for the reduced German trading volume, it is not necessarily true that an ADR program stimulates volume in the home market as one might conclude from the pooled results. Researchers may find a focus on analysis of cross-listing effects at the individual-firm level to be more fruitful and revealing than the traditional focus on aggregating across many firms. 


\section{References}

Alexander, G.; Eun, C. S.; and Janakiramanan, S. 1988. International listings and stock returns: Some empirical evidence. Journal of Financial and Quantitative Analysis 23: 135-151.

Cantale, S. 1996. The choice of a foreign market as a signal. Working Paper. INSEAD.

Choi, F.D.S., and Levich, R.M. 1990. The capital market effects of international accounting diversity. Homewood, Illinois: Dow Jones-Irwin.

Errunza, V.R., and Losq, E. 1985. International asset pricing under mild segmentation: Theory and test. Journal of Finance 40: 105-124.

Eun, C., and Janakiramanan, S. 1986. A model of international asset pricing with a constraint on the foreign equity ownership. Journal of Finance 41: 897914.

Foerster, S. R., and Karolyi, G. A. 1993. International listings of stocks: The case of Canada and the U.S. Journal of International Business Studies 24: 763784.

Foerster, S. R., and Karoyli, G. A. 1999. The effects of market segmentation and investor recognition on asset prices: Evidence from foreign stocks listing in the United States. Journal of Finance 54: 981- 1013.

Fuerst, O. 1998. A theoretical analysis of the investor protection regulations argument for global listing of stocks. Working Paper. Yale School of Management.

Miller, D. P. 1999. The market reaction to international cross-listings: Evidence from depositary receipts. Journal of Financial Economics 51: 103-123.

Saudagaran, S., and Biddle, G. 1995. Foreign listing location: A study of MNCs and stock exchanges in eight countries. Journal of International Business Studies 26: 119-141.

Smith, K., and Sofianos, G. 1997. The Impact of an NYSE listing on the global trading of non-U.S. stocks. Working paper \#97-02. New York Stock Exchange.

Stapleton, R., and Subrahmanyam, M. 1977. Market imperfections, capital market equilibrium and corporation finance. Journal of Finance 32: 307-319. 